\title{
Microwave-assisted pyrolysis of seaweed biomass for aromatics-containing bio-oil production
}

\author{
Xinyun Wang ${ }^{1}$, Chuan $\mathrm{Li}^{1}$, Mingqiang Chen ${ }^{2, *}$, and Jun Wang ${ }^{2}$ \\ ${ }^{1}$ School of Chemistry and Materials Engineering, Chaohu University, Chaohu, 238000, China \\ ${ }^{2}$ School of Chemical Engineering, Anhui University of Science and Technology, Huainan232001, China
}

\begin{abstract}
Microwave-assisted pyrolysis of seaweed biomass was conducted using a microwave pyrolysis system. The product yields were determined and the components of bio-oil were analyzed by a gas chromatography-mass spectrometry (GC-MS). Results showed that as the pyrolysis temperature increased from $400{ }^{\circ} \mathrm{C}$ to $600{ }^{\circ} \mathrm{C}$, the gas yield increased and the bio-char yield decreased. However, the bio-oil yield rose firstly and then reduced. The maximal bio-oil yield was $18.4 \mathrm{wt} . \%$ when pyrolysis temperature was $500{ }^{\circ} \mathrm{C}$. The bio-oil obtained is a mixture of very complex organic compounds, mainly consisting of aldehydes, ketones, alcohols, esters, phenols, aliphatic hydrocarbons, aromatic hydrocarbons and nitrogencontaining compounds. The relative content of aromatics in bio-oil accounted for about $16 \%$. The above results reveal that microwave-assisted pyrolysis of seaweed biomass is a feasible method to produce aromatics-containing bio-oil.
\end{abstract}

\section{Introduction}

With the continuous depletion of fossil fuels and the increasingly serious environmental pollution caused by burning of fossil fuels, biomass, as a renewable and carbon-neutral energy resource, have aroused more and more attention all over the world. Biomass resources mainly include lignocellulosic biomass(woody plants and herbaceous plants) and algal biomass. The main components of lignocellulosic biomass and algae are different. Lignocellulosic biomass is mainly composed of cellulose, hemicellulose and lignin [1]. However, algae mainly consists of protein, lipid and carbohydrate, which are easy to be pyrolyzed $[2,3]$. Compared with terrestrial biomass, algae have the advantages of faster growth speed and shorter growth cycle [4]. Moreover, they do not compete in land use for food production. Algae as the third generation of feedstocks are the promising energy resources [5]. Algae are found in fresh water or marine water environments and can be generally classified into microalgae and macroalgae (also called seaweeds) [6]. Compared with microalgae, seaweed has shown the some advantages, such as high yield and easy large-scale cultivation in the sea.

Pyrolysis is an attractive method to convert solid biomass into high energy density pyrolytic oils, bio-char and gas. Pyrolysis is defined as the thermal decomposition of biomass by heat in the absence of oxygen which produces solid (bio-char), liquid (bio-oil) and gaseous products, whose yields and components depend on pyrolysis conditions and feedstock characteristics. Bio-oil can be directly used to fuel internal combustion engines or can be used as chemical feedstocks [1]. Microwave irradiation is an alternative heating method. [7, 8]. Compared with convectional heating processes where heat is transferred from the surface to the inside of the material, microwave radiation heating is the direct conversion of electromagnetic energy into heat at the molecular level [9], therefore, it can provide uniform internal heating for material particles. However, biomass is a poor microwave absorber due to low-loss dielectric properties. To achieve the temperature necessary to carry out the pyrolysis, microwave-assisted pyrolysis of biomass is possible, if the raw material is mixed with an effective microwave absorbent materials, such as biomass char and activated carbon [10].

In recent research, although, bio-oil production from microwave-assisted pyrolysis with different microwave absorbents has already been successfully applied to different terrestrial biomass [11-14], there are few studies have been aimed at obtaining bio-oil from microwave-assisted pyrolysis of seaweeds [15]. The ocean areas in the word counts for nearly three-fourths of the earth's surface, so seaweed resources are very abundant. Microwave-assisted pyrolysis of seaweed for bio-fuels production is of great practical significance in solving the energy crisis. In this study, the product yields, the components of bio-oil product from microwaveassisted pyrolysis of seaweed were investigated.

* Corresponding author: mqchen@aust.edu.cn 


\section{Materials and methods.}

\subsection{Materials}

The biomass sample of the seaweed Ulva lactuca ( $U$. lactuca) was collected from Huiquan Bay, Qingdao, Shandong Province, China. The samples were air dried and then ground and sieved to less than $0.2 \mathrm{~mm}$ in size. $\mathrm{SiC}$ were used as microwave absorbent. Microwave absorbent, SiC was purchased from the Shanghai Milling Material \& Tool Co. Ltd., China. The particle size of SiC is about

\subsection{Characterization of seaweed biomass}

The proximate analysis of $U$. lactuca was conducted according to GB212-91 standard of China. The fixed carbon content was calculated by the difference. A elemental analyser (Vario ш, Germany) was used to determine the ultimate analysis of sample. O content was calculated by the difference. The heating value of $U$. lactuca sample was determined on an adiabatic bomb calorimeter (C6000, IKA (Guangzhou) works Co., Ltd., Guangzhou, China).

\subsection{Apparatus and procedure}

Microwave-assisted pyrolysis experiments were conducted with a microwave oven described in our previous report [1]. The microwave oven has a maximum power of $2000 \mathrm{~W}$ at a frequency of $2450 \mathrm{MHz}$. For each experiment, the mixture of uniform mixed $20 \mathrm{~g}$ of the $U$. lactuca with $20 \mathrm{~g}$ of $\mathrm{SiC}$ was placed in the lower zone of a quartz reactor. Then, the quartz reactor was placed in the microwave cavity. The carrier gas $\left(\mathrm{N}_{2}\right)$ flow rate of $0.5 \mathrm{~L} / \mathrm{min}$ was introduced into microwave pyrolysis reactor for $10 \mathrm{~min}$ and then was set to 0.3 $\mathrm{L} / \mathrm{min}$. After that, the microwave oven was turned on and microwave power was set to a $800 \mathrm{~W}$. The pyrolysis temperature was set at $400{ }^{\circ} \mathrm{C}, \quad 500{ }^{\circ} \mathrm{C}, \quad 600{ }^{\circ} \mathrm{C}$, respectively, and then held constant for $2 \mathrm{~min}$. The biooil was collected from three U-shaped tubes immersed in ice water condenser and weighed. The non-condensable gaseous product was discharged into the atmosphere. After microwave-assisted pyrolysis, solid char and $\mathrm{SiC}$ were separated by sieving based on the difference in their particle size. The yields of the solid char and bio-oil were calculated from the weight of each fraction, while the yield of the gas was calculated by the difference. In this study, each experiment was repeated at least three times to ensure accuracy of the experimental result. The data are the average values of three times with less than $5 \%$ difference.

\subsection{Components analysis of bio-oil product}

The components analysis of the bio-oil product was carried out on a Shimadzu GC-MS (QP5050, Japan) with a capillary column $(\mathrm{DB}-17,30 \mathrm{~m} \times 0.25 \mathrm{~mm}$ i.d. $\times 0.25$ $\mu \mathrm{m})$. Prior to analysis, the moisture of the bio-oil fraction was removed using anhydrous sodium sulfate. Acetone was used as a solvent to dilute the dehydrated bio-oil. The solvent cut time was $2 \mathrm{~min}$. The detector temperature was set to $230{ }^{\circ} \mathrm{C}$ and that of injection was set to $300{ }^{\circ} \mathrm{C}$. The oven temperature program was in the following: firstly maintained at $60{ }^{\circ} \mathrm{C}$ for $4 \mathrm{~min}$, then increased to $140{ }^{\circ} \mathrm{C}$ with a heating rate of $10{ }^{\circ} \mathrm{C} / \mathrm{min}$. After that, the temperature was increased to $150{ }^{\circ} \mathrm{C}$ with a heating rate of $1{ }^{\circ} \mathrm{C} / \mathrm{min}$. Next, the temperature was increased to $250{ }^{\circ} \mathrm{C}$ with a heating rate of $20{ }^{\circ} \mathrm{C} / \mathrm{min}$. Finally, the temperature was increased to $280{ }^{\circ} \mathrm{C}$ with a heating rate of $5{ }^{\circ} \mathrm{C} / \mathrm{min}$ and kept for $5 \mathrm{~min}$. The injection size was $1 \mu \mathrm{L}$ with a split ratio of $20: 1$. High pure helium $(99.999 \%)$ with a flow rate of $1 \mathrm{~mL} / \mathrm{min}$ was used as a carrier gas. The MS detector was operated in the electron ionization mode $(70 \mathrm{eV})$ with an ionization temperature of $230{ }^{\circ} \mathrm{C}$. The mass spectra were recorded in the interval $50-500 \mathrm{~m} / \mathrm{z}$. The compounds of bio-oil were identified by comparing their respective mass spectra with those from the National Institute of Standards and Technology (NIST) mass spectral database.

\section{Results and discussion}

\subsection{Seaweed sample characterization}

The results of ultimate and proximate analysis of $\mathrm{U}$. lactuca seaweed sample are listed in Table 1.

Table 1. Proximate and ultimate analysis of sample.

\begin{tabular}{|c|c|c|c|c|}
\hline \multicolumn{4}{|c|}{ Ultimate analysis (ad, wt.\%) } & \multirow{2}{*}{$\begin{array}{l}\text { Heating } \\
\text { value } \\
(\mathrm{MJ} / \mathrm{kg})\end{array}$} \\
\hline Moisture & Volatile & Ash & $\begin{array}{c}\text { Fixed } \\
\text { Carbon }\end{array}$ & \\
\hline 4.93 & 61.41 & 26.00 & 12.59 & 13.32 \\
\hline \multicolumn{5}{|c|}{ Ultimate analysis (ad, wt.\%) } \\
\hline $\mathbf{C}$ & $\mathbf{H}$ & $\mathbf{N}$ & $\mathbf{S}$ & $\mathbf{O}$ \\
\hline 30.85 & 5.12 & 2.47 & 0.95 & 33.61 \\
\hline
\end{tabular}

ad: air dry basis; wt.\%, mass percentage.

The results of ultimate analysis and proximate analysis are in agreement with the previous reports [16, 17]. The ash content of $U$. lactuca sample is higher in comparison to lignocellulosic biomass [13], most likely due to seaweed saline growing environment. The $\mathrm{N}$ content of the seaweed is higher than that of lignocellulosic biomass [18]. This is related to its higher protein content in seaweed sample [18].

\subsection{Effect of pyrolysis temperature on product yields}

The product yields of microwave-assisted pyrolysis of seaweed $U$. lactuca at various temperatures with a microwave power of $800 \mathrm{~W}$ are given Figure 1. 
It can be seen evidently that as the pyrolysis temperature increased from $400{ }^{\circ} \mathrm{C}$ to $600{ }^{\circ} \mathrm{C}$, the biooils yield increased and then decreased. The highest biooil yield of 18.4 wt.\% was obtained at pyrolysis temperature of $500{ }^{\circ} \mathrm{C}$. Above the pyrolysis temperature of $500{ }^{\circ} \mathrm{C}$, the gases yield was higher due to breaking of some pyrolysis vapors into non-condensable gases. Moreover, the biochar yield was observed lower with with the increase of pyrolysis temperature, which might be because of secondary reaction happening at high pyrolysis temperatures [19].

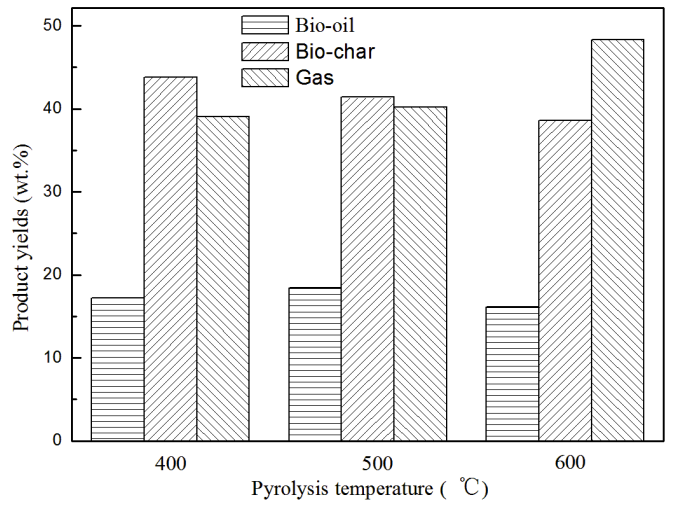

Fig. 1. Effect of pyrolysis temperatures on products yields

\subsection{Bio-oil compositions analysis}

Both the qualitative and quantitative analyses of chemical compositions of bio-oil from microwaveassisted pyrolysis of $U$. lactuca were carried out using GC-MS. The GC-MS chromatogram at the pyrolysis temperature of $500{ }^{\circ} \mathrm{C}$ is shown in Figure 2 and the detailed relative content (peak area percentage) of the main compositions of the bio-oil are listed in Table 2 .

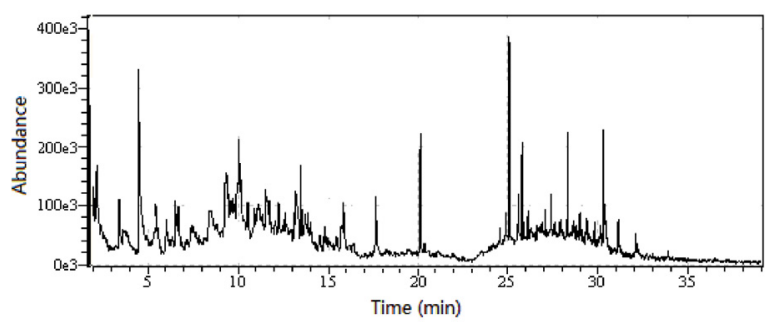

Fig. 2. Total ion chromatograms of bio-oil derived from microwave-assisted pyrolysis of $U$. lactuca

It can be seen that bio-oil is a complex mixture of organic compounds consisting of a wide range of organic chemical groups. The identified compounds mainly included aldehydes/ketones, alcohols, esters, phenols, aliphatic hydrocarbons, aromatic hydrocarbons and nitrogen-containing compounds. Aldehydes, ketones and alcohols were mainly derived from thermal degradation of carbohydrate compounds in seaweed feedstock [20]. Aliphatic hydrocarbons such as alkanes, alkenes are generated during the depolymerization of saturated and unsaturated fatty acids in seaweed biomass [21]. The aromatics were mainly formed through the decomposition, oligomerization, cyclization and aromatization of lipids followed by carbohydrates, while protein has the least contribution to the formation of aromatics under pyrolysis-gas chromatography/mass spectrometry (Py-GC/MS) with HZSM-5 catalyst [22]. Monocyclic aromatic hydrocarbons such as toluene, benzene and styrene are important constituent for good bio-oil quality, which are served as important industrial chemicals, transportation fuel additives to increase octane number, while polycyclic aromatic hydrocarbons (PAHs) such as naphthalene and anthracene are recognized as toxic compounds [23]. Monocyclic aromatic hydrocarbons in the bio-oil mainly included Benzene (2.92\%), Toluene (3.88\%), Styrene (3.46\%), (2methyl-3-butenyl)-Benzene (2.42\%). 1-methylene-1HIndene $(3.07 \%)$ is only one of PAHs detected in the biooil. The total content of aromatics accounted for about $16 \%$. The formation of monocyclic aromatic hydrocarbons is also probably produced by a polycondensation reaction between aldehydes and ketones [24], so, the contens of aldehydes and ketones in the bio-oil is very low. The bio-oil contained more

Table 2. Main organic components of bio-oil obtained from microwave-assisted pyrolysis of $U$. lactuca

\begin{tabular}{|c|c|c|}
\hline Bio-oil compositions & Formula & $\begin{array}{c}\text { Relative } \\
\text { content }(\%)\end{array}$ \\
\hline \multicolumn{3}{|l|}{ Aldehydes } \\
\hline Hexadecanal & $\mathrm{C}_{16} \mathrm{H}_{32} \mathrm{O}$ & 3.16 \\
\hline \multicolumn{3}{|l|}{ Ketones } \\
\hline $\begin{array}{l}\text { 2,5-Dimethyl-4-hydroxy-3(2H)- } \\
\text { furanone }\end{array}$ & $\mathrm{C}_{6} \mathrm{H}_{8} \mathrm{O}_{3}$ & 2.52 \\
\hline Oxabicyclo[6.1.0]nonan-4-one & $\mathrm{C}_{8} \mathrm{H}_{12} \mathrm{O}_{2}$ & 2.40 \\
\hline \multicolumn{3}{|l|}{ Alcohols } \\
\hline 2-Butene-1,4-diol & $\mathrm{C}_{4} \mathrm{H}_{8} \mathrm{O}_{2}$ & 5.57 \\
\hline 1-Octanol, 3,7-dimethyl- & $\mathrm{C}_{10} \mathrm{H}_{22} \mathrm{O}$ & 1.04 \\
\hline E-2-Tetradecen-1-ol & $\mathrm{C}_{14} \mathrm{H}_{28} \mathrm{O}$ & 5.75 \\
\hline \multicolumn{3}{|l|}{ Esters } \\
\hline Ethyl acetate & $\mathrm{C}_{4} \mathrm{H}_{8} \mathrm{O}_{2}$ & 12.31 \\
\hline \multicolumn{3}{|l|}{ Phenols } \\
\hline Phenol & $\mathrm{C}_{6} \mathrm{H}_{6} \mathrm{O}$ & 2.63 \\
\hline \multicolumn{3}{|l|}{ Aliphatic hydrocarbons } \\
\hline Nonane, 2,6-dimethyl- & $\mathrm{C}_{11} \mathrm{H}_{24}$ & 0.83 \\
\hline 1-Tetradecene & $\mathrm{C}_{14} \mathrm{H}_{28}$ & 7.06 \\
\hline 1-Tridecyne & $\mathrm{C}_{13} \mathrm{H}_{24}$ & 1.22 \\
\hline 3-Dodecene, (E)- & $\mathrm{C}_{12} \mathrm{H}_{24}$ & 1.10 \\
\hline 2-Undecene, 3-methyl-, (Z)- & $\mathrm{C}_{12} \mathrm{H}_{24}$ & 1.24 \\
\hline \multicolumn{3}{|l|}{ Aromatic hydrocarbons } \\
\hline Benzene & C6H6 & 2.92 \\
\hline Toluene & C7H8 & 3.88 \\
\hline Styrene & $\mathrm{C} 8 \mathrm{H} 8$ & 3.46 \\
\hline Benzene, (2-methyl-3-butenyl)- & $\mathrm{C}_{11} \mathrm{H}_{14}$ & 2.42 \\
\hline 1H-Indene, 1-methylene- & $\mathrm{C}_{10} \mathrm{H}_{8}$ & 3.07 \\
\hline \multicolumn{3}{|l|}{ Nitrogen-containing compounds } \\
\hline 1H-Pyrrole & $\mathrm{C}_{4} \mathrm{H}_{5} \mathrm{~N}$ & 10.42 \\
\hline 1H-Pyrrole, 3-methyl- & $\mathrm{C}_{5} \mathrm{H}_{7} \mathrm{~N}$ & 3.15 \\
\hline 2-Ethynyl pyridine & $\mathrm{C}_{7} \mathrm{H}_{5} \mathrm{~N}$ & 3.63 \\
\hline Benzonitrile, 3-methyl- & $\mathrm{C}_{8} \mathrm{H}_{7} \mathrm{~N}$ & 1.01 \\
\hline Indolizine & $\mathrm{C}_{8} \mathrm{H}_{7} \mathrm{~N}$ & 3.15 \\
\hline Indole & $\mathrm{C}_{8} \mathrm{H}_{7} \mathrm{~N}$ & 0.86 \\
\hline Tetradecanamide & $\mathrm{C}_{14} \mathrm{H}_{29} \mathrm{NO}$ & 3.73 \\
\hline
\end{tabular}


more nitrogen-containing compounds, mainly pyrrole, pyridine, indole and amide. The total content of nitrogen-containing compounds was up to $26 \%$. The formation of nitrogen-containing compounds in the biooil was resulted from the decomposition of protein, which was related to its high content of nitrogen in seaweed sample [18].

It was note that the major compounds of bio-oil from conventional pyrolysis of macroalgae are phenols, pyrroles and furans followed by nitriles, pyrazoles, pyridines, benzenes, alkanes and so on [25]. The nitrogen-containing compounds is significant high, however, the monocyclic aromatic hydrocarbons compounds is very low. This indicates that microwaveassisted pyrolysiscan promote the deamination of protein, which further are transformed into monocyclic aromatic hydrocarbons.

\section{Conclusions}

In the present study, microwave-assisted pyrolysis of seaweed biomass was investigated. The yields of three phase, the chemical compositions of bio-oil were studied. With the increase of pyrolysis temperature, the gas yield rose and the bio-char yield reduced. While, the bio-oil yield increased initially and then decreased, the highest bio-oil yield of $18.4 \mathrm{wt} . \%$ was obtained at $500^{\circ} \mathrm{C}$. The identified chemical compounds of the bio-oil mainly contained aldehydes/ketones, alcohols, esters, phenols, aliphatic hydrocarbons, aromatic hydrocarbons and nitrogenous compounds. The relative content of aromatics reached to about $16 \%$. In future, the microwave-assisted catalytic pyrolysis should be taken into consideration in order to increase aromatics of the produced bio-oil product.

\section{Acknowledgements}

This work was financially supported by the Natural Science Research Program of Anhui Provincial Higher Education Institutions (No. KJ2019A0679).

\section{References}

1. X. Wang, G. Qin, M. Chen, J. Wang, BioResources, 11 (2016) 6125-6136.

2. H. Zhao, H. Yan, M. Liu, C. Zhang, B. Sun, S. Dong, S. Qin, Energy Sources, Part A, 34 (2012) 1958-1966.

3. X. Wang, X. Wang, G. Qin, M. Chen, J. Wang, J. Therm. Anal. Calorim., 132 (2018) 1317-1323.

4. S. Wang, B. Cao, Y. Feng C. Sun, Q. Wang, E.F. Abomohra, S. Afonaa-Mensah, Z. He, B. Zhang, L. Qian, L. Xu, J. Therm. Anal. Calorim., 135 (2019) 2613-2623.

5. O. Norouzi, S. Jafarian, F. Safari, A. Tavasoli, B. Nejati, Bioresour. Technol., 219 (2016) 643-651.
6. T. Suganya, M. Varman, H.H. Masjuki, S. Renganathan, Renew. Sustai. Energy Rev., 55 (2016) 909-941.

7. M. Miura, H. Kaga, A. Sakurai, T. Kakuchi, K. Takahashi, J. Anal. Appl. Pyrol., 71(2004) 187-199.

8. M. Chen, J. Wang, M. Zhang, M. Chen, X. Zhu, F. Min, Z. Tan, J. Anal. Appl. Pyrol., 82 (2008) 145150.

9. W. Xie, J. Liang, H.M. Morgan, X. Zhang, K. Wang, H. Mao, Q. Bu, J. Anal. Appl. Pyrol.,132 (2018) 163-170.

10. A. Dominguez, J.A. Menendez, M. Inguanzo, J.J. Pis, Bioresour. Technol., 97 (2006) 1185-1193.

11. J. Xie, O. Trierweiler, Y. Cheng, Y. Wan, Y. Liu, R. Zhu, X. Lin, P. Chen, R. Ruan, Bioresour. Technol., 156 (2014) 267-274.

12. A. Mamaeva, A. Tahmasebi, L. Tian, J. Yu, Bioresour. Technol., 211 (2016) 382-389.

13. X. Wang, F. Wu, C. Li, M. Chen, J. Wang, BioResources 13 (2018) 5479-5490.

14. H. Wu, L. Wang, G. Ji, H. Lei, H. Qu, J. Chen, F. Wang, J. Liu, J. Anal. Appl. Pyrol., 151 (2020) 104902.

15. R. Gautam, S. Shyam, B. Rajasekhar Reddy, K. Govindaraju, R. Vinu, Sustain. Energy Fuels 3 (2019): 3009-3020.

16. Y. Hu, S. Wang, Q. Wang, Z. He, X. Lin, S. Xu, H. Ji, Y. Li, Proc. Combust. Inst., 36 (2017) 2271-2281.

17. W. Gao, K. Chen, J. Zeng, J. Xu, B. Wang, Bioresour. Technol., 243 (2017) 212-217.

18. T. Yuan, A.Tahmasebi, J. Yu, Bioresour. Technol., 175 (2015) 333-341.

19. C. Ma, J. Geng, D. Zhang, X. Ning, J. Energy Inst., 93 (2020) 303-311.

20. B. Maddi, S. Viamajala, S. Varanasi, Bioresour. Technol., 102 (2011) 11018-11026.

21. T. Aysu, A. Sanna, Bioresour. Technol., 194 (2015) 108-116.

22. Z. Du, B. Hu, X. Ma, Y. Cheng, Y. Liu, X. Lin, Y. Wan, H. Lei, P. Chen, R. Ruan, Bioresour. Technol., 130 (2013) 777-782.

23. B. Cao, S. Wang, Y. Hu, A.E.F. Abomohra, L. Qian, Z. He, Q. Wang, B.B. Uzoejinwa, S. Esakkimuthu, Renew. Energy 138 (2019) 29-38.

24. S. Wang, Q. Wang, X. Jiang, X. Han, H. Ji, Energy Convers. Manage., 68 (2016) 273-280.

25. N. Ferrera-Lorenzo, E. Fuente, I. Suarez-Ruiz, R.R. Gil, B. Ruiz, J. Anal. Appl. Pyrol., 105 (2014) 209216. 